This item was submitted to Loughborough's Research Repository by the author.

Items in Figshare are protected by copyright, with all rights reserved, unless otherwise indicated.

\title{
Complex geographies of play provision dis/investment across the UK
}

PLEASE CITE THE PUBLISHED VERSION

http://dx.doi.org/10.1080/21594937.2015.1106042

PUBLISHER

(c) Taylor and Francis

VERSION

AM (Accepted Manuscript)

PUBLISHER STATEMENT

This work is made available according to the conditions of the Creative Commons Attribution-NonCommercialNoDerivatives 4.0 International (CC BY-NC-ND 4.0) licence. Full details of this licence are available at: https://creativecommons.org/licenses/by-nc-nd/4.0/

\section{LICENCE}

CC BY-NC-ND 4.0

\section{REPOSITORY RECORD}

McKendrick, John H., Peter Kraftl, Sarah Mills, Stefanie Gregorius, and Grace Sykes. 2019. "Complex Geographies of Play Provision Dis/investment Across the UK". figshare. https://hdl.handle.net/2134/19371. 


\section{Complex geographies of play provision dis/investment across the UK John H McKendrick ${ }^{1}$, Peter KraftI ${ }^{2}$, Sarah Mills ${ }^{3}$, Stefanie Gregorius ${ }^{4}$, and Grace Sykes ${ }^{5}$}

\section{Wyatt loses his house in Wyoming, Beatrice loses her park in Battersea}

The unravelling of the US housing market in late 2006 triggered a series of events that have had far-reaching consequences not only for the global economy, but also for children's play and playwork in the UK. In the aftermath of the Global Recession of 2009, the UK elected a new Government in 2010, which immediately implemented an 'austerity programme', seeking to reduce the Government budget deficit. Within three months, notice had been served of cuts to play provision in England. The Education Secretary wrote to local authorities advising them not to utilise unspent monies that had been allocated to them under the previous administration's Playbuilder programme (DCSF \& DCMS, 2008), unless there was clear evidence of a contractual arrangement to progress construction (Vasagar, 2010). The unravelling of the transformation that was envisaged of England's play landscape was cemented in October of that year when the Minister again wrote to Directors of Children's Services in English local authorities to advise them of the 'saving' of $£ 20.8$ million of the $£ 75$ million that had been allocated for play capital budget spend in 2010-11 (Gove, 2010). Further, less overt, cuts to play funding were to follow. These cuts can be understood in the wider context of disproportionate cuts, through UK Government spending reviews, to public services for children and young people (NSPCC, 2011) and to consequent increases in levels of child poverty and deprivation (CRAE, 2013).

As it is not a statutory service, play is particularly vulnerable to secondary cuts, i.e. local cutbacks to service provision that, in this instance, were a consequence of the UK Government reducing the budgets of local Government by 7\% per annum from 2010 to 2014 (HM Treasury, 2010). As local Government struggles to fulfil its statutory obligations, severe cuts to nonstatutory services such as play have followed. In some authorities this has been achieved through outsourcing of service. In the London Borough of Camden, for instance, it is not clear how many of the 200 playworkers who lost their jobs have been absorbed by the community-led service that now delivers play locally (Morton, 2012a; 2012b). What can be said with certainty is that the reconfiguration of the playground in Battersea Park in the London Borough of Wandsworth from a renowned open-access adventure playground to one with fixed equipment in landscaped grounds was one that was not welcomed by the local community (The Spectacle Blog, 2013) and play professionals alike (Hocker, 2014). Furthermore, it should be noted that children, who are arguably most affected by these developments, hardly have a voice in the political decision making process (Bosco, 2010).

\section{The Leicester seminar: Playwork in Times of Austerity}

In May of 2013, the Geographies of Children, Youth and Families Research Group of the Royal Geographical Society (with IBG) organised a one-day seminar at the University of Leicester to discuss the issue of Playwork in Times of Austerity. The idea behind the event was to provide a 
forum in which academic geographers and playwork practitioners could consider the issues and responses to what was pre-conceived as a contemporary 'crisis' for play in the UK. In addition to Mick Conway, the keynote speaker, ruminating on a long and distinguished playwork career (Conway, 2014), the deliberations comprised two sets of three formal papers to the themes of 'cuts in focus' and 'rethinking what matters', wrapped around a Pecha Kucha session of nine mini-presentations, which provided concise and focused commentary on very specific aspects of 'play and austerity.'

In terms of the academic geographers who attended, the seminar was situated particularly within cross-disciplinary research on children's everyday spaces, places and movements. Within academic geography, this research has come to be known as 'Children’s Geographies', although, like the journal of the same name, this work encapsulates work by geographers, anthropologists, sociologists and others (Kraftl et al., 2012). Research on Children's Geographies has several affinities with that on play and playwork. On the one hand, it emphasises the diverse everyday experiences of children in their localities - especially in outdoor spaces - and the ways in which they negotiate adult-imposed regulations (e.g. Holt, 2011). On the other hand, such research has examined how space and place - especially institutions like schools - are central to the construction of contemporary notions of childhood, on which many assumptions about the parameters of children's play are founded (e.g. Holloway and Valentine, 2000; Holloway et al., 2010).

This collection in the International Journal of Play brings together seven of the papers from the Leicester seminar, each of which focused on the broader implications for play in UK society (a smaller collection, which focused on issues for playwork practitioners, was published in the Journal of Playwork Practice - McKendrick et al. 2014). Four themes are addressed in this collection, i.e. 'how did we get here'; 'austerity as threat'; 'austerity as opportunity'; and 'rethinking play and society'. In thinking through the significance for play of 'the era of austerity', it is important to acknowledge that there are other significant and recent developments that may help understand the ways in which austerity has impacted on play in the UK, two of which are now introduced.

\section{The construction and consumption of the national narrative for play in the UK}

The play and playwork sector in the UK has presented a convincing and wide-ranging case for investing in play. As Tim Gill explains in more detail in the opening paper in this collection, the years around the Millennium were ones in which the play sector was challenged to articulate the value of play (Playlink, NPFA and Children’s Play Council, 2000), which in turn, led to unprecedented levels of national investment in children's play by the UK Government and other national bodies (Department of Culture, Media and Sports, 2004).

A strong narrative from the UK play sector in recent years has been that play is about more than play. It has been argued with conviction that play can make a positive contribution to achieving a wide range of socially desirable goals (Play England, 2009). For example, among other virtues, play is promoted as a means through which children's learning can be enhanced (Scottish Government, nd; Kraftl, 2013), obesity can be tackled (National Toy Council, nd), and social inclusion can be promoted (Playboard NI, nd; Skelton, 2009). Such acknowledgments resonate with Children's Geographies research, which has examined the challenges and opportunities facing children's play in diverse geographical contexts.

The diffusion of the case for play is also evident in the proliferation of advice that has been generated to facilitate play in different settings; these have been underpinned by evidence-based 
reviews. For example, Play Scotland and CPIS have published a range of factsheets that provide guidance on how to facilitate play in a wide range of environments including institutional settings (schools and hospitals), social settings (intergenerational play and playtime) and environmental settings (natural environments, sand play, wooded areas) (CPIS, nd; Play Scotland, nd).

On the other hand, play is also promoted as a whole, as well as for its parts. A fundamental tenet of the sector's play principles is acknowledgment of the value of play for its own sake (Skillsactive, nd). The Playwork Principles are not alone in promoting play per se; most definitions of play in the UK, and all of those that originate from within the play sector, make reference to play being 'freely chosen', 'personally driven' and 'intrinsically motivated' (e.g. Russell and Lester, 2008).

Although the UK play sector has risen to the challenge of articulating the value of play, it is less clear how this message has been received. While others (especially Early Years Educators) welcomed the acknowledgement of the contribution that play makes to achieving their goals, it is less clear whether the inherent value of play is a message that has been as warmly welcomed by those outside the play profession. Indeed, the same Minister for Education who initiated the play cuts in 2010, demonstrated an alarming misunderstanding of the value of play in the Autumn of 2013 in recalling an ancedote from schools in Kent. In a speech in which he acknowledged the importance of teaching, he reported that, "Some schools have been pressured to fit in with prevailing doctrines, even against their own instincts. Some nurseries and schools in Kent, for example, reported to us that ... [they] were told that children were not allowed to tidy up, or be asked to put their coats on, in case it interrupted 'child-initiated play"” (Gove, 2013). Setting aside the gross misrepresentation of child-initated play that this represents, that a Government minister considers that there is political capital to be gained by ridiculing children's play in such a fashion should be troubling to the play sector in the UK, as it suggests that there is a wider public that would be receptive to such a message.

\section{Changing play: the role of the local state and the emergence of the devolved national region in lean times}

As the examples from London in the opening section of this paper suggest, the political geographies of play in the UK are not stable. On the contrary, the role of the state in relation to play is ridden with tensions between the opposing forces of centralisation and de-centralisation (Hulme et al., 2013).

Playgrounds and play spaces are more than merely sites for play: the geographies of play matter across a variety of scales. Gagen (2000) demonstrates how the development of municipal playgrounds in US cities in the early $20^{\text {th }}$ century reflected the concerns of social reformers to shape child development, in order to produce ‘American' identities that were both gendered and racialised. Through time, the provision of play spaces extended beyond showpiece provision and such national ideals, and was woven into the fabric of neighbourhoods at a more local scale. As Cunningham and Jones (1999) outline, town planners were at the fore in promoting such formal play space in the residential environments that they were creating in the mid-late $20^{\text {th }}$ century. On the other hand, playgrounds are not merely provided by the local state or by other interest groups for communities; campaigning for, and the construction of, neighbourhood playgrounds is also a grassroots activity led by community groups who desire these spaces (Hetherington, 1999). Thus, by the end of the $20^{\text {th }}$ century, it was widely accepted that playground playspace 
should be available where children were expected to play, i.e. in residential environments and municipal parks.

The public provision of playspace by the local state in the UK was politicised when local government expenditure contracted in the 1970s and 1980s. This co-incided with the development of a national consciousness for play, as national and regional collectives of play workers developed from the grassroots. Once the recipient of playspace, communities, aligned with playworkers, were now agitating against the local state to protect their community resource.

The development of a UK national frame of reference for play fractured in the 1990s with the introduction of Devolution. Play was within the remit of the new Devolved Administrations in Scotland, Wales and Northern Ireland, while the UK Government retained responsibility for play in England. Different devolution pathways for play followed, leading to a distinct spatial patternings of play at the sub-national level in the UK. In England, the central state adopted a prominent role, directing and directly funding significant investment in play infrastructure. A strong Play England emerged, as did strong regional associations for play in England. Play also developed in the devolved national regions in the 1990s, but on a much smaller scale and at a much slower pace. All three of the national play associations in devolved UK strengthened (Play Scotland, Play Wales and Playboard NI) and there were some significant national commitments to play in Wales, such as in 2002 when Wales became the first country in the world to adopt a national play policy (Play Wales, nd, a). However, on the whole, the scale of investment was much more modest in Scotland, Wales and Northern Ireland, when compared to England.

As noted above, a change of government in 2010 heralded the introduction of a 'politics of austerity', through which an opportunity was provided for the new Government to further its ideological commitment to a 'smaller' central state. Consequently, the UK state has adopted a less prominent role in funding play. The Department for Education, which had (as the Department for Children, Schools and Families) led government initiatives on play in England, stated in April 2011 that 'full responsibility for play will be returned to local authorities and their communities' (Burlington, 2011). It is not without consequence, that this scalar shift in the responsibility for play from central to local government coincides with a significant reduction in the monies available to local government.

This 'return' to localism in play provision in England contrasts with the situation in Wales, Scotland and Northern Ireland, where national governments have adopted a more prominent role in supporting play. The Scottish Government introduced Scotland's first National Play Strategy in 2013 (Scottish Government, 2013); a Play Sufficiency Duty came into force in Wales in November 2012 as part of their anti-poverty drive (Section 11 of the Children and Families (Wales) Measure 2010 - Play Wales, nd, b); and the NI Executive endorsed a Play and Leisure Strategy and Implementation Plan for Northern Ireland in March 2011 (OFMDFM, 2011). Even here, the political geography is complex, with the national state investing in play at a time when, as in England, the local state is finding it more difficult to continue supporting it.

\section{Introduction to this collection}

The papers in this edited collection are organised into four themes, each of which comprises two papers. The opening theme - How We Got Here - presents insider and outsider accounts of the recent history of play investment in England. In this first, Tim Gill, one of the UK's leading thinkers on contemporary childhood and a highly respected and leading figure in the UK play sector for several decades (e.g. Gill, 2007), shares his thoughts from when he was seconded in 
2002 to the then Department for Culture, Media and Sport from his position as Director of the Children's Play Council (now Play England) to lead the first ever UK Government sponsored review of children's play. Tim makes it clear that play in England is shaped by the wider society of which it is part; both benefitting from opportunities presented, and now suffering from constraints that it imposes. In the second paper, insights from the 'back end' of this era of investment are provided by Alexandra Long, Senior Lecturer in Playwork at Leeds Metropolitan University. Having worked as a Play Manager in Bradford (North Yorkshire) and Camden (London) throughout the 2000s, Alexandra reflects on the legacy of the Big Lottery programme evaluation, which followed the investment of $£ 123$ million in England between 2006 and 2012 (Smith and Day, 2011). Alexandra fears for the consequences of the play sector not embracing its own 'objectives for play provision' as a framework to evidence the value of investment in play in times of austerity (and beyond).

Austerity as threat, the second theme, also comprises two complementary papers. Helen Woolley, Reader in Landscape Architecture and Society at the University of Sheffield, explores the nature and implication of austerity cuts in the city of Sheffield, a city of half a million people in the north of England. Helen finds little comfort in the way in which the city is responding to the cuts, with retraction of provision to be found in many forms. John McKendrick (Board of Directors of Play Scotland and Glasgow Caledonian University) and Chris Martin (UNITE Union's Playwork Convenor) then provide an overview of the cuts in Scotland and SW England, two parts of the UK with contrasting play trajectories in recent times. They identify limitations in speaking 'collectively' about play and playwork in the UK, as they explore the extent to which the wider funding context for play services is reflected in play practitioners' reflections on their experiences in 2013.

The third theme, Austerity as Opportunity, considers the possibility that austerity need not (only) be problematic. For Alice Ferguson (Director of Playing Out) and Angie Page (University of Bristol) the disinvestment from provision of formal public playspace affords opportunities for communities to rediscover their streets as play spaces. Presenting both an insider and outsider perspective, this paper extols the value of street play for its potential to transform both the everyday residential environment and children's physical health. Rob Wheway (Children's Play Information Service) is also supportive of outdoor play. However, rather than seek the organised grassroots creation of street playspace, he seeks to champion the cause of 'free play'. Rob's argument is grounded on a career's worth of field observations in which it is consistently demonstrated that children travel only very short distances to access neighbourhood play.

Rethinking Play and Society is the final theme. Arthur Battram (Plexity) argues that there is a need to rethink the general orientation of play in the UK and the tendency to posit play futures as a straight choice of between strategic playwork and environmental playwork. Arthur articulates a 'third way' for play, one which is less concerned with infrastructure (or accessing that infrastructure) and is primarily concerned to engender a culture that is more supportive of play. Finally, Cindy Regaldo, (University College London) articulates the case that playfulness is a fruitful strategy to deploy in advancing 'publicly initiated scientific research'. Here, a wider role for play is envisaged that is integral to progressive grassroots community development action.

Finally, the authors of this editorial return in conclusion to summarise the key points. We identify six overarching themes to emerge across the papers and consider the significance for the future of play in the UK, and beyond. 


\section{References}

Bosco, Fernando J. (2010) "Play, work or activism? Broadening the connections between political and children's geographies.” Children's Geographies 8.4: 381-390.

Burlington, S. (2011) Letter to Eleanor Thompson, 4Children in responses to questions submitted to the Department for Education). April 6, 2011. Available at: http://www.4children.org.uk/Files/b7f98172-1fec-4ffa-b72b-a21c00c9932e/110406-Replyto-APPG-on-Sure-Start-from-DfE.pdf [Accessed 15 November 2013].

Children’s Play Information Service [CPIS]. nd. "Factsheets.” Available online at: http://www.ncb.org.uk/cpis/resources/factsheets [Accessed 14 November 2014].

CRAE Children's Rights Alliance for England [CRAE] (2013) State of Children's Rights in England: Review of Government action on United Nations' recommendations for strenghtening children's rights in the UK. London: CRAE.

Conway, M. (2014), “The Thin of it - Surviving and Thriving in Austerity.” Journal of Playwork Practice 1: 87-91.

Cunningham, C. J. and Jones, M. A. (1999) “The Playground: A Confession of Failure?” Built Environment 25.1: 11-17.

DCMS (2004) Getting Serious About Play. A Review of Children's Play. London: TSO

DCSF and DCMS (2008) The Play Strategy. London: TSO

Gagen, E. (2000) "An Example to us all: Child Development and Identity Construction in Early 20th-century Playgrounds.” Environment and Planning A 32.4: 599-616.

Gill, T. (2007) No Fear: Growing up in a Risk Averse Society. Calouste Gulbenkian Foundation.

Gove, M. (2010) Michael Gove's Letter to Directors of Children's Services. October 20, 2010.

Available at: https://www.gov.uk/government/publications/revised-play-capital-allocationsfor-local-authorities [Accessed 14 November 2013].

Gove, M. (2013) Michael Gove Speaks About the Importance of Teaching. September 13, 2013. Available at: https://www.gov.uk/government/speeches/michael-gove-speaks-about-theimportance-of-teaching [Accessed 14 November 2013].

Hetherington, S. (1999) "Playgrounds as Community Landscapes.” Built Environment 25.1: 2534.

Hocker, P. (2014), “A play space to beat all.” Journal of Playwork Practice 1: 104-108.

Holloway, S. and Valentine, G. (2000) "Spatiality and the new social studies of childhood," Sociology 34.4: 763-783.Holloway, Sarah, Phil Hubbard, Heike Joens and Helena PimlottWilson. 2010. "Geographies of education and the significance of children, youth and families", Progress in Human Geography, 34: 583-600.

Holt, L. (2011) Geographies of Children, Youth and Families: International Perspectives. London: Routledge.

Hulme, R., McKay, J. and Cracknell, D. (2013) "From Commissar to Auctioeer? The changing role of directors in managing children's services in a period of austerity,” Educational Management, Administration and Leadership, doi: 10.1177/1741143213494886

HM Treasury (2010) Spending Review 2010. London: TSO Available at: https://www.gov.uk/government/uploads/system/uploads/attachment_data/file/203826/Spen ding_review_2010.pdf [Accessed 14 November 2013]. 
Kraftl, P., Horton, J. and Tucker, F. (2013) Critical Geographies of Childhood and Youth: Contemporary Policy and Practice. Bristol: Policy Press.

Kraftl, P. (2013) Geographies of Alternative Education: Diverse Learning Spaces for Children and Young People. Bristol: Policy Press.

McKendrick, J.H., Horton, J. Kraftl, P. and Else, P. (2014)“Space for Playwork in Times of Austerity?” Journal of Playwork Practice 1: 79-118.

Morton, K. (2012a) Camden to Close Play Services, Nursery World, January 18, 2012. Available at: http://www.nurseryworld.co.uk/article/1112784/camden-close-playservices?HAYILC=RELATED [Accessed 7 November 2013].

Morton, K. (2012b) Camden Council Launches New Play Service, Nursery World, September 14, 2012. Available at: http://www.nurseryworld.co.uk/article/1150110/camden-councillaunches-new-play-service?HAYILC=RELATEDNSPCC [Accessed 7 November 2013] NSPCC (2011) Smart Cuts? Public Spending on Children's Social Care. CIPFA/NSPCC.

National Toy Council. nd. Active Play and Health. London. Available at: http://www.btha.co.uk/wp-content/uploads/2012/10/active_play.pdf [Accessed 14 November 2014].

Office of the First Minister and Deputy First Minister (2011) Play and Leisure Implementation Plan. Belfast. Available at:

http://www.northernireland.gov.uk/play_and_leisure_implementation_plan.pdf [Accessed 8 November 2013].

Playboard NI. nd. Play and Social Inclusion. Belfast. Available at: http://www.playboard.org/Uploads/document/180820091434-2137642286.pdf [Accessed 14 November 2014].

PLAYLINK, NPFA and the Children's Play Council (2000) Best Play: What Play Provision Can Do For Children. London: NPFA

Play England (2011) “Government to Discontinue National Play Contracts.” February 14, 2011. Available at: http://www.playengland.org.uk/news/2011/02/government-to-discontinuenational-play-contracts.aspx [Accessed 15 November 2014].

Play Scotland. nd. "Factsheets." Available online at: http://www.playscotland.org/resources/factsheets/ [Accessed 14 November 2014].

Play Wales. nd, a. Play Wales Timeline. Available online at: http://www.playwales.org.uk/login/uploaded/documents/INFORMATION\%20SHEETS/pla y\%20in\%20wales\%20timeline.pdf [Accessed 15 November 2014].

Play Wales. nd, b. "Play Sufficiency." Available at: http://www.playwales.org.uk/eng/sufficiency [Accessed 8 November 2013].

Russell, W. and Lester, S. (2008) Play For a Change: Play policy and practice. A review of contemporary perspectives. Play England.

Scottish Government (2013) Play Strategy for Scotland: Our Vision. Edinburgh. Available at: http://www.scotland.gov.uk/Resource/0042/00425722.pdf [Accessed 8 November 2013].

Skelton, T. (2009) “Children’s Geographies/Geograhies of children: Play, Work, Mobilities and Migration.” Geography Compass 3.4: 1430-1448.

Skillsactive. nd. Playwork Principles. Available at: http://www.skillsactive.com/oursectors/playwork/playwork-principles [Accessed 14 November 2013].

Smith, N. and Day, L. (2011) Children’s Play Programme Evaluation. Final Report to Big Lottery Fund. Birmingham: Ecorys. 
Spectacle Blog (2013) “New Playground in Battersea Park.” April 30, 2013. Available at: http://www.spectacle.co.uk/spectacleblog/tag/battersea-park-adventure-playground-2/ [Accessed 14 November 2013].

Scottish Government. nd. “Play, Talk, Read.” Available at: http://www.playtalkread.org [Accessed 14 November 2013].

Vasagar, J. (2010) “Playground Plans Shelved Under Government Spending Cuts.” The Guardian, August 11, 2010. Available online at: http://www.theguardian.com/politics/2010/aug/11/playground-plans-frozen-spending-cuts [Accessed 14 November 2013].

John McKendrick has been a member of the Board of Directors of Play Scotland since 2007. He is also a human geographer based at Glasgow Caledonian University and Workshop Convenor of the Geographies of Children, Youth and Families Research Group of the Royal Geographical Society (with IBG) (hereafter, GCYFRG). He has edited three collections of papers on children and children's play in the UK (Playgrounds in the Built Environment, Built Environment, 1999; First Steps: An Introduction to the Geographies of Children, Youth and Families, 2004; and Space for Playwork in Times of Austerity, Journal of Playwork Practice, 2014), He has also completed a series of research projects for Play Scotland, and addressed conferences and seminars for Play England, Play Scotland, PlayBoard NI, and many regional play bodies in the UK. Peter Kraftl is a Professor in Human Geography at the University of Birmingham. He was until recently Chair of the GCYFRG and an editor of the journal Children's Geographies.. In 2013, he published Geographies of Alternative Education (Policy Press) and in 2012 he co-edited Critical Geographies of Childhood and Youth (Policy Press). He is the author of over fifty journal articles and book chapters on childhood and education. Sarah Mills is a Senior Lecturer in Human Geography at Loughborough University and Chair of GCYFRG. Her interests are in the complex geographies, spaces and subjectivities of youth citizenship and her research has explored uniformed youth organisations in the UK. Along with Peter Kraftl, she is the coeditor of Informal Education, Childhood \& Youth: Geographies, Histories, Practices (Palgrave Macmillan, 2014). Stefanie Gregorius is a recently completed postgraduate student at Loughborough University and a GCYFRG Committee Member. Her research has focused on the transtions to adulthood of youth with disabilities in Accra, Ghana. at the University of Leicester. Her research interests include; children and young people; spaces of education (both formal and informal); and creative participatory methods. 